\title{
An Improved Efficiency of Integrated Inverter / Converter for Dual Mode EV/HEV Application
}

\author{
A. S. S. Veerendra Babu ${ }^{1}$, P. Bala Krishna ${ }^{2}$, R. Venkatesh ${ }^{3}$ \\ ${ }^{1}$ Assistant Professor, Department of EEE, ADITYA College of Engineering, Surampalem, A.P, India \\ ${ }^{2}$ Assistant Professor, Department of EEE, ADITYA college of Engineering, Surampalem, A.P, India \\ ${ }^{3}$ Assistant Professor, Department of EEE, ADITYA college of Engineering, Surampalem, A.P, India
}

\begin{abstract}
The objective of this paper is to improve the efficiency of EV/HEV under heavy load conditions. The proposed integrated circuit allows the permanent magnet synchronous motor to operate in motor mode or acts as boost inductors of the boost converter and thereby boosting the output torque coupled to the same transmission system or dc-link voltage of the inverter connected to the output of the integrated circuit. In motor mode, the proposed integrated circuit acts as an inverter and it becomes a boost-type boost converter, while using the motor windings as the boost inductors to boost the converter output voltage.. The proposed control technique is to use interleaved control to significantly reduce the current ripple and thereby reducing the losses and thermal stress under heavy-load condition. The performance of the proposed circuit is available by using simulation of MATLAB/SIMULINK software
\end{abstract}

Keywords: Hybrid Electric Vehicles (HEV), Boost Converter, Electric Vehicles (EV), Internal Combustion Engine (ICE)

\section{Introduction}

IN PARALLEL hybrid electric vehicle (HEV) [1]-[3] and electric vehicle (EV) [4], [5] system as shown in Fig. 1, the converter is used for boosting the battery voltage to rated dc bus for an inverter to drive motor. In the multimotor drive system [6], [7], the system will use two or more motors to boost torque, especially under low speed and high-torque region as shown in Fig. 2. For such applications, two or more inverters/converters are required. Fig. 3 shows the application of the proposed integrated circuit for motor drives with dual-mode control for EV/HEV applications. As shown in Fig. 3, the proposed integrated circuit allows the permanent magnet synchronous motor (PMSM) to operate in

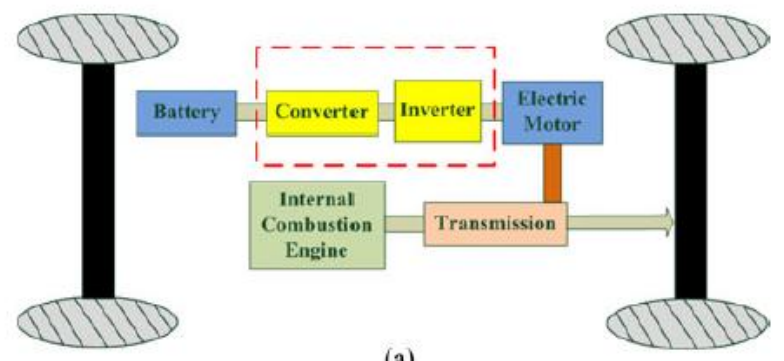

(a)

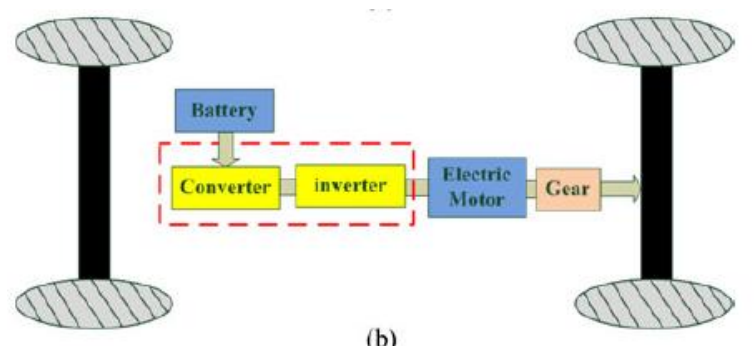

(b)

Figure 1: HEV and EV system (a) Parallel HEV drive train. (b) EV drive train.

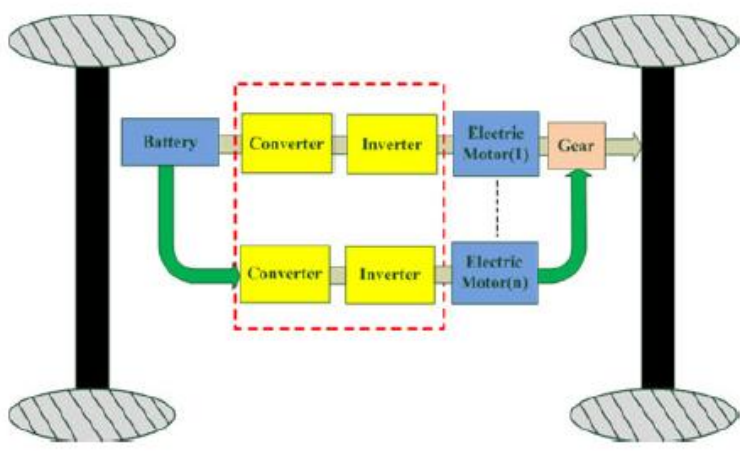

Figure 2:Conventional multi motor drive system of EV/HEV

motor mode or acts as boost inductors of the boost converter and thereby, boosting the output torque coupled to the same transmission system or dc-link voltage of an inverter connected to the output of the integrated circuit. In motor mode, the proposed integrated circuit acts as an inverter and it becomes a boost-type boost converter, while using the motor windings as the boost inductors to boost the converter output voltage. Therefore, the proposed integrated circuit can significantly reduce the volume and weight of the system.

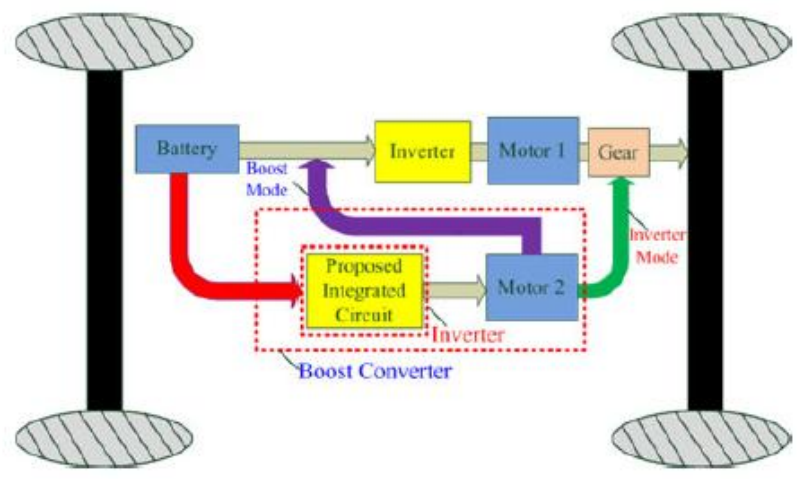

Figure 3: Proposed integrated inverter/converter for the multi motor drive system 


\section{International Journal of Science and Research (IJSR) \\ ISSN (Online): 2319-7064 \\ Index Copernicus Value (2013): 6.14 | Impact Factor (2014): 5.611}

The integrated circuit presented in this paper can act as an inverter and a boost converter depending on the operation mode. For the integrated circuit, it not only can reduce the volume and weight but also boost torque and dc-link voltage for motor/converter modes, respectively. Moreover, a new control technique for the proposed integrated circuit under boost converter mode is proposed to increase the efficiency. For conventional circuit, shown in Fig. 4, a single phase boost converter [8] has been widely used for boost control due to its simplicity. However, for higher power applications, an interleaved boost converter [9]-[13] can reduce the

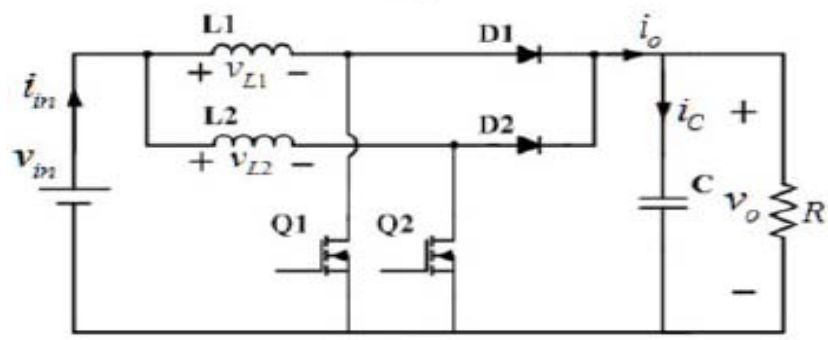

Figure 4: Single phase Interleaved boost converter.

current ripple and components stress and thereby reducing the losses and thermal stress. Based upon the interleaved control idea, a boost-control technique using motor windings as boost inductors for the proposed integrated circuit will be proposed. Under light load, the integrated circuit acts as a single-phase boost converter for not invoking additional switching and conduction losses, and functions as the twophase interleaved boost converter under heavy load to significantly reduce the current ripple and thereby reducing the losses and thermal stress. Therefore, the proposed control technique for the proposed integrated circuit under boost converter mode can increase the efficiency.

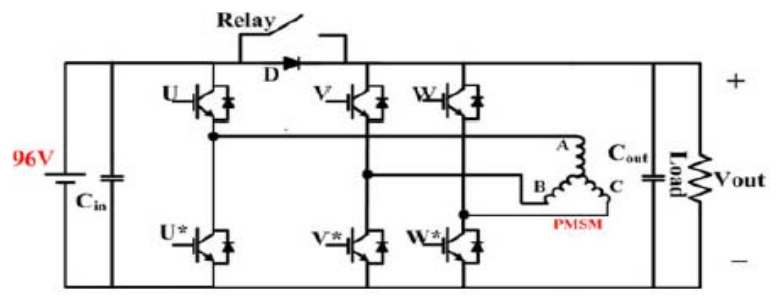

Figure 5: Integrated circuit for dual mode of motor of motor drives and boost converter

Table 1: Specifications of Components

\begin{tabular}{|c|c|}
\hline Component & Specification \\
\hline $\mathrm{C}_{\mathrm{in}} / \mathrm{C}_{\text {out }}$ & $330 \mathrm{uF} / 450 \mathrm{~V}$ \\
\hline Diode & $\mathrm{V}_{\mathrm{R}}=500 \mathrm{~V}, \mathrm{I}_{\mathrm{F}}=20 \mathrm{~A}, \mathrm{~V}_{\mathrm{F}}=0.87 \mathrm{~V}$ \\
\hline IGBT & $\mathrm{V}_{\mathrm{CE}}=600 \mathrm{~V}, \mathrm{I}_{\mathrm{C}}=75 \mathrm{~A}$, \\
& $\mathrm{V}_{\mathrm{CE} \text { (sat) }}=1.5 \mathrm{~V}$ \\
\end{tabular}

\section{Proposed Integrated Circuit and Control Technique}

\section{A.Proposed Integrated Inverter/Converter Circuit}

Fig. 5 shows the integrated circuit for dual-mode control. In Fig. 5, Cin and Cout can stabilize the voltage when input and output voltages are disturbed by source and load, respectively. Diode $(D)$ is used for preventing output voltage impact on the input side. When the integrated circuit is operated in inverter (motor) mode, relay will be turned ON and six power devices (IGBTs in Fig. 5) are controlled by pulse width modulation (PWM) control signals. Details of the component specifications are shown in Table I.

When the proposed integrated circuit is operated in the converter mode, relay is turned OFF. And a single-phase or inter leaved control method will be applied to control of the power devices depending upon the load conditions.
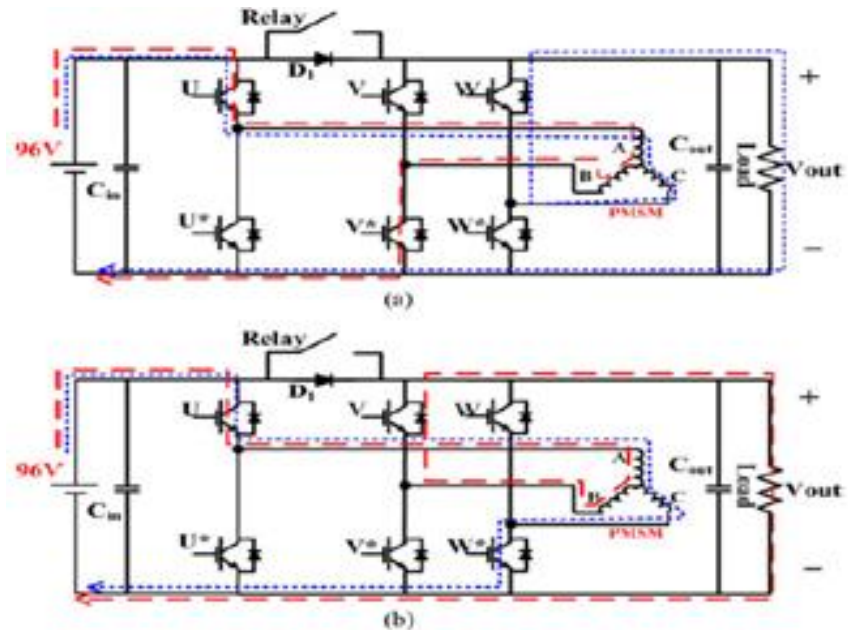

Figure 6: Proposed interleaved boost mode.

(a) Phase B - charge; $\quad$ Phase C- Discharge;

(b) Phase B - Discharge; Phase C- Charge

Figs. 6 show the single-phase and two-phase interleaved boost converters. In Fig.6, two-phase interleaved boost converter uses power switches $V^{*}$ and $W^{*}$, stator winding " $A$," winding " $B$," and winding " $C$ " to boost the output voltage and reduce the current ripple.

\section{B. Modelling and Controller Design Under Boost Mode}

This section will introduce the model of boost converter and derive the transfer function of the voltage controller. Fig. 7 shows the nonideal equivalent circuit of the boost converter, it considers nonideal condition of components: inductor winding resistance $R L$, collector-emitter saturation voltage

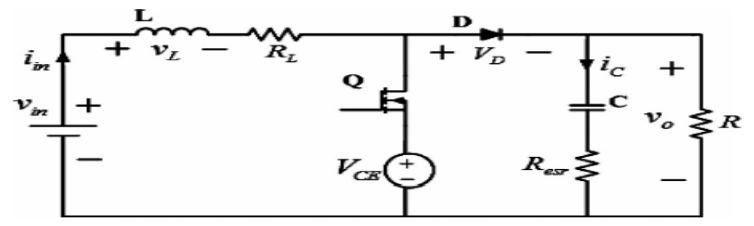

Figure 7: Equivalent circuit of the boost converter.

VCE, diode forward voltage drop $V D$, and equivalent series resistance of capacitor Resr .

Analysis of the boost converter by using the state-space averaging method [14], small-signal ac equivalent circuit can be derived, as shown in Fig. 8. 


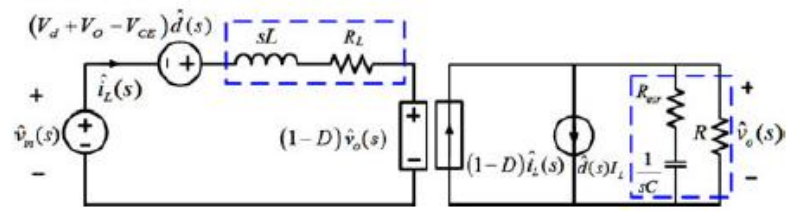

Figure 8: Small-signal equivalent circuit

By Fig. 8, the transfer function of the voltage controller can be derived as shown in (1).

Table 2: Controller Design Parameters

\begin{tabular}{|c|c|}
\hline$V_{\text {in }}$ & $96 \mathrm{~V}_{\mathrm{DC}}$ \\
\hline$V_{o}$ & $288 \mathrm{~V}_{\mathrm{DC}}$ \\
\hline$P_{o}$ & $3 \mathrm{~kW}$ \\
\hline$C$ & $260 \mu \mathrm{F}$ \\
\hline$R_{L}$ & $170 \mathrm{~m} \Omega$ \\
\hline$L$ & $2.77 \mathrm{mH}$ \\
\hline$R_{e s r}$ & $108 \mathrm{~m} \Omega$ \\
\hline$V_{d}$ & $0.462 \mathrm{~V}$ \\
\hline$V_{C E}$ & $1.5 \mathrm{~V}$ \\
\hline Voltage drop of $D$ & $0.87 \mathrm{~V}$ \\
\hline
\end{tabular}

Substituting the parameters shown in Table II into (1) give

$$
\mathrm{G}_{\mathrm{vd}}(\mathrm{s})=\frac{-6.737 \times 10^{5} \mathrm{~s}^{2}+0.06827 \mathrm{~s}+2498}{2.004 \times 10^{-5} \mathrm{~g}^{2}+0.00409 \mathrm{~g}+2.242}
$$

Fig. 9 shows the block diagram of voltage loop, using a proportional-integral (PI) controller for the compensator. In this paper, the switching frequency is $20 \mathrm{kHz}$ and voltage loop bandwidth will be less than $2 \mathrm{kHz}$. And the phase margin should be more than $45^{\circ}$ to enhance the noise immunity. For the designed controller shown in (3), the Bode plot of the closed loop gain as shown in Fig. 10, the bandwidth is $7.73 \mathrm{~Hz}$ and the phase margin is $91.8^{\circ}$

$$
\begin{aligned}
& \mathrm{C}(\mathrm{s})=\frac{0,0249897 s+12007 \mathrm{~g}}{s} \\
& \mathrm{G}_{\mathrm{vd}}(\mathrm{s})=\frac{\mathrm{V}_{0}(s)}{d(s)}=
\end{aligned}
$$

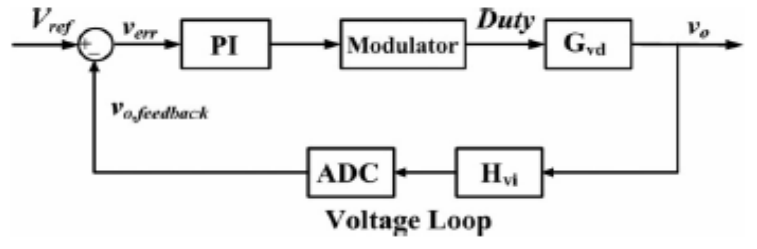

Figure 9: Block diagram of voltage loop

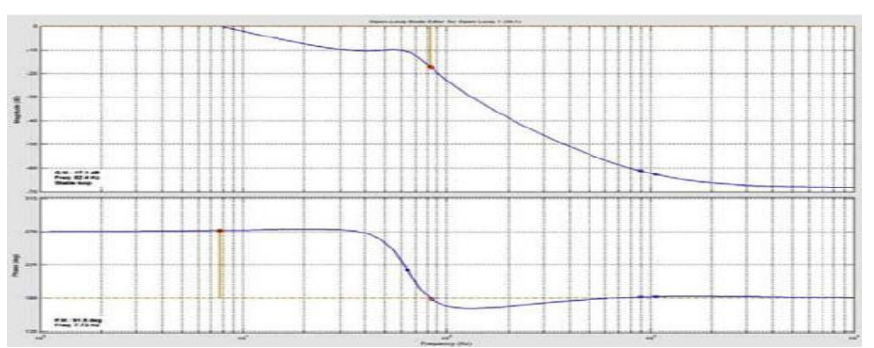

Figure 10: Bode plot, voltage control,B.W. $=7.73 \mathrm{~Hz}$ and P.M. $=91.8^{0}$

\section{Simulation Results}

Here the simulation carried by two different cases they are 1) Proposed interleaved boost converter multiplier module 2) $\mathrm{PV}$ as input source of proposed converter with interleaved boost converter

Case-1 Proposed interleaved boost converter

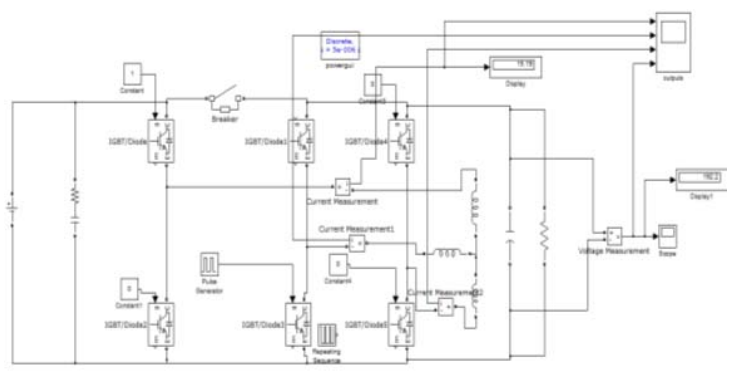

Figure 11: Matlab/simulink model of the integrated circuit and controller 
International Journal of Science and Research (IJSR)
ISSN (Online): 2319-7064

Index Copernicus Value (2013): 6.14 | Impact Factor (2014): 5.611

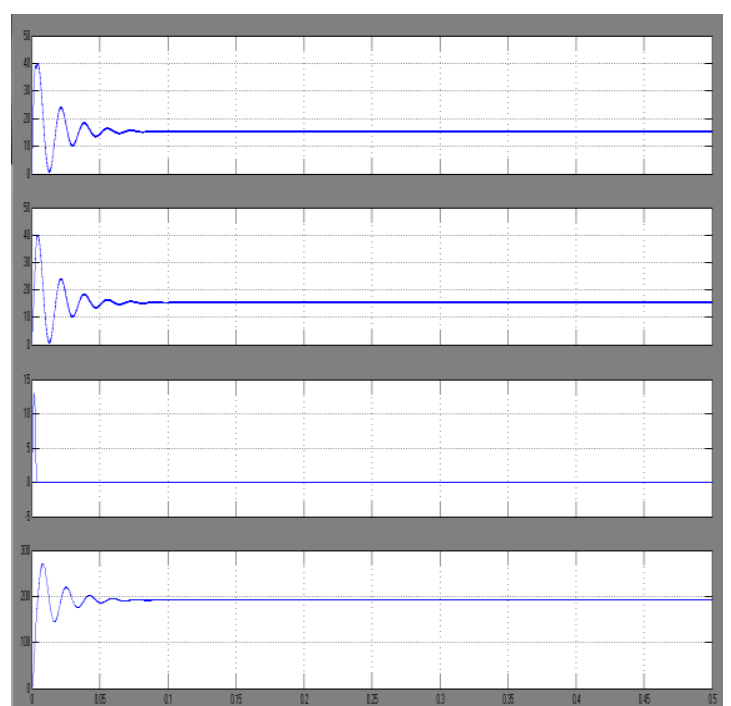

Figure 11.1: measured current with and without interleaved control, Single-phase interleaved boost converter

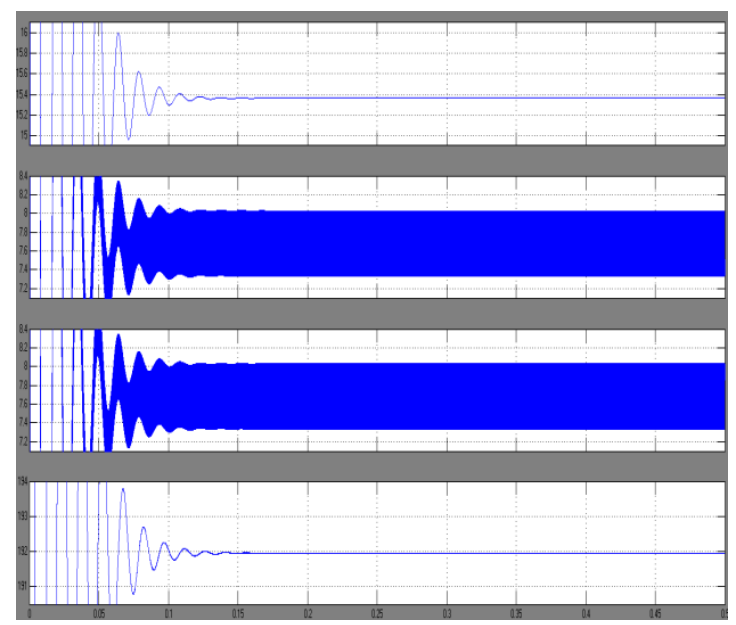

Figure 11.2: Measured current with and without interleaved control, Two-phase interleaved boost converter

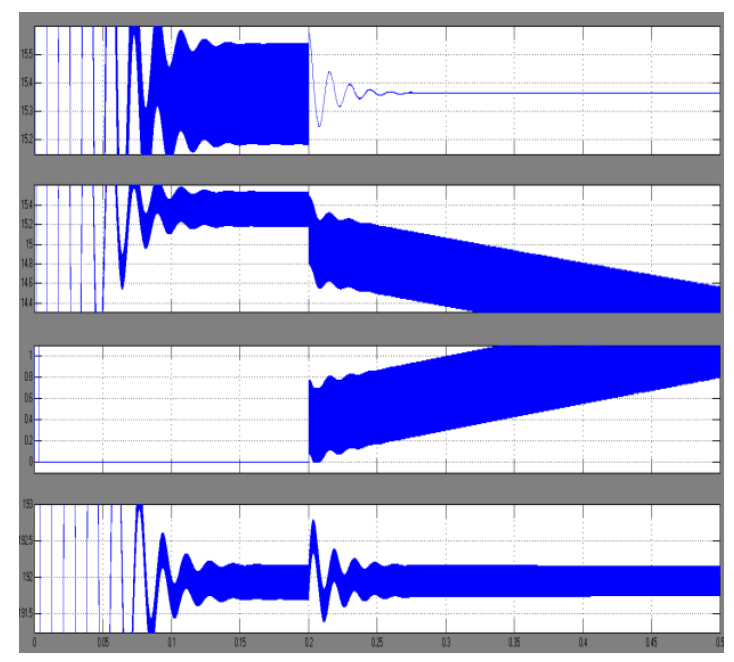

Figure 11.3: simulated waveforms for the transition between single-phase control and two-phase interleaved control from two-phase interleaved to single-phase modes.

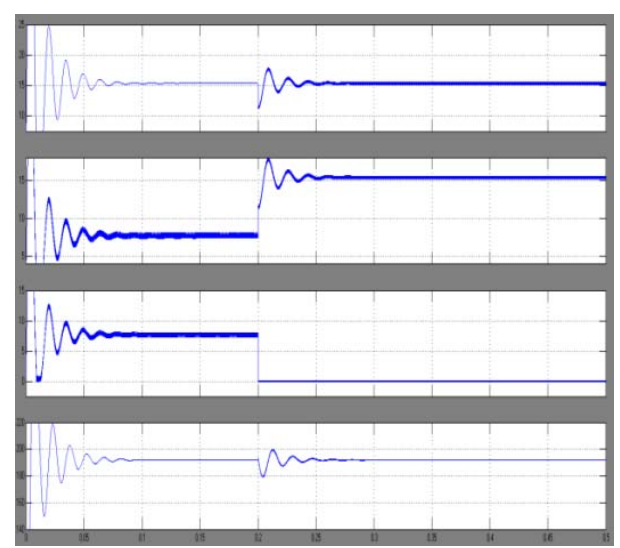

Figure 11.4: simulated waveforms for the transition between single-phase control and two-phase interleaved control single-phase to two-phase interleaved modes

Case-2 proposed interleaved boost converter with closed loop operation

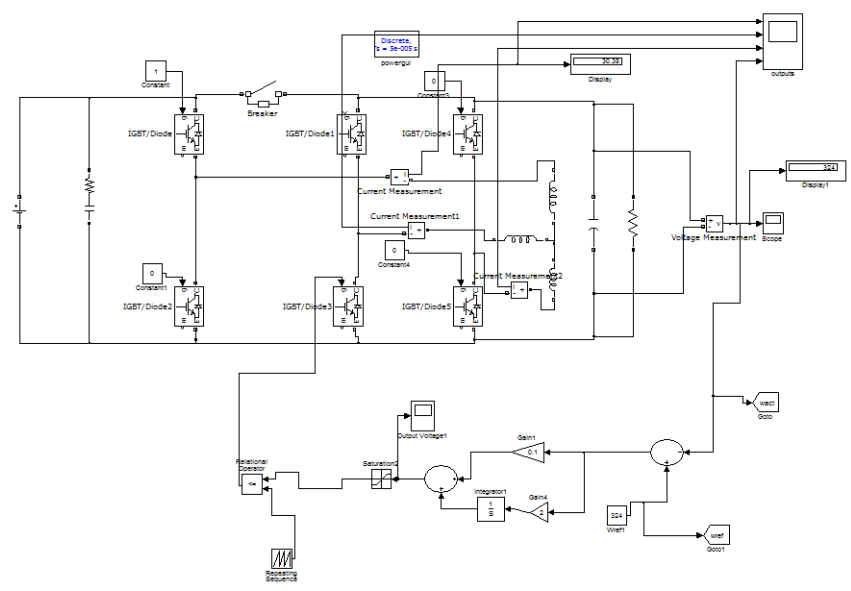

Figure 12: Matlab/Simulink model of the proposed single phase converter with closed loop operation

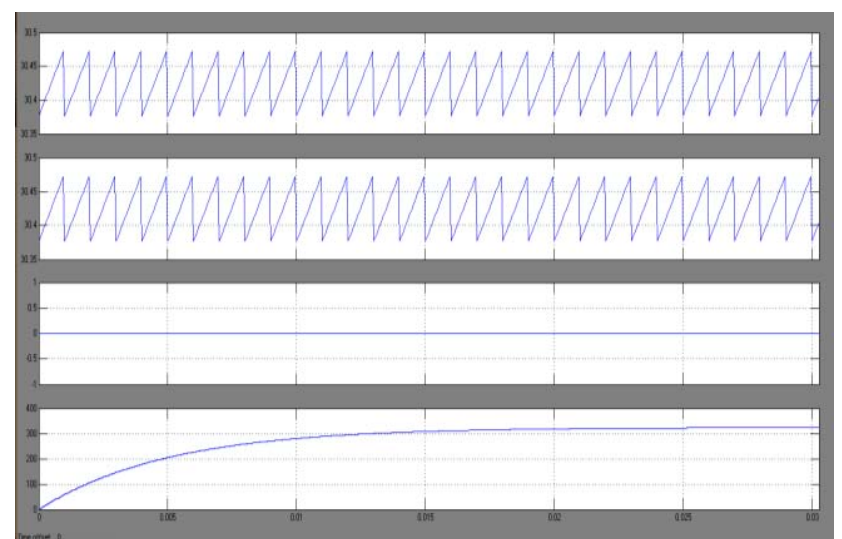

Figure 12.1: Simulated output wave forms of the closed loop control of the single phase converter with reference value $324 \mathrm{~V}$ 


\section{International Journal of Science and Research (IJSR) \\ ISSN (Online): 2319-7064}

Index Copernicus Value (2013): 6.14 | Impact Factor (2014): 5.611

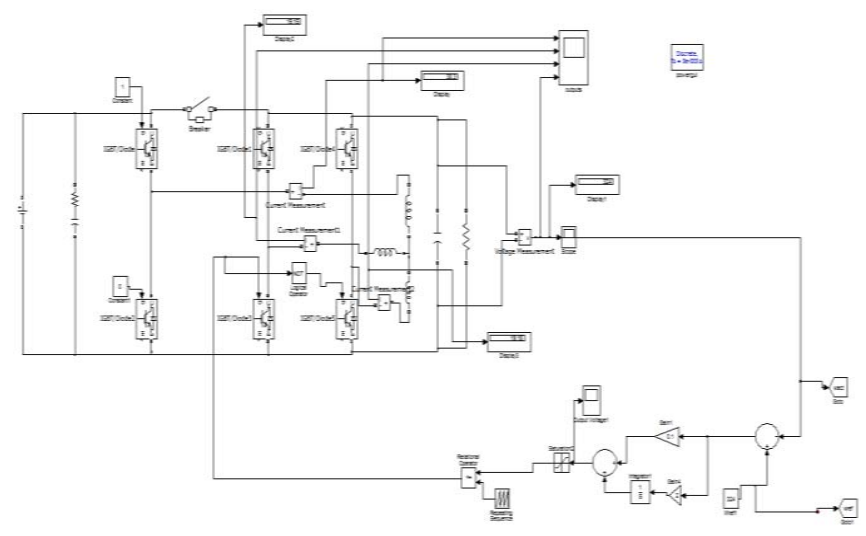

Figure 13: Matlab/Simulink model of the proposed two phase converter with closed loop operation.

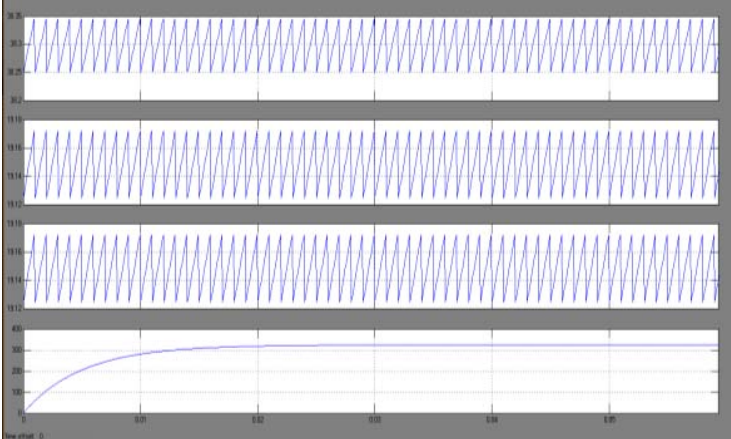

Figure 13.1: Simulated output wave forms of the closed loop control of the Two phase interleaved converter with reference value $324 \mathrm{~V}$

\section{Conclusion}

The contributions of this paper include:

1)Proposal of a new integrated inverter/converter circuit of motor drives with dual-mode control for EV/HEV applications to significantly reduce the volume and weight;

2)Proposal of a new control method for the integrated inverter/ converter circuit operating in boost converter mode to increase the efficiency;

3) Verification of the proposed integrated inverter/converter circuit;

4) Verification of the proposed control method. Experimental results show that the voltage boost ratio can go up to 3 . Under full-load condition, the maximum efficiency is more than $96 \%$ and efficiency can be maintained at more than $91.9 \%$ for voltage ratios varies from 1.25 to 3 . These results fully confirm the claimed merits of the proposed integrated circuit and control method.

\section{References}

[1] M. Habib Ullah, T. S. Gunawan, M. R. Sharif, and R. Muhida, "Design of environmental friendly hybrid electric vehicle," in Proc. IEEE Conf. Comput. Commun. Eng., Jul. 2012, pp. 544-548.

[2] O. Hegazy, J. Van Mierlo, and P. Lataire, "Analysis, modeling, and implementation of a multidevice interleaved DC/DC converter for fuel cell hybrid electric vehicles," IEEE Trans. Power Electron., vol. 27, no. 11, pp. 4445-4458, Nov. 2012.
[3] W. Qian, H. Cha, F. Z. Peng, and L. M. Tolbert, "55-kW Variable 3X DCDC Converter for plug-in hybrid electric vehicles," IEEE Trans. Power Electron., vol. 27, no. 4, pp. 1668-1678, Apr. 2012.

[4] M. Yilmaz and P. T. Krein, "Review of battery charger topologies, charging power levels, and infrastructure for plug-in electric and hybrid vehicles," IEEE Trans. Power Electron., vol. 28, no. 5, pp. 2151-2169, May 2013.

[5] G. Maggetto and J. Van Mierlo, "Electric and electric hybrid vehicle technology: A survey," in Proc. IEE Semin. Electric, Hybrid Fuel Cell Vehicles, Apr. 2000, pp. 1-1-111.

[6] J. Zhang, X. H.Wen, and L. Zeng, "Optimal system efficiency operation of dual PMSM motor drive for fuel cell vehicles propulsion," in Proc. IEEE Int. Power Electron. Motion Control Conf., May. 2009, pp. 18891892.

[7] J. Zhang, X. H. Wen, and Y. L. Wang, "Research on optimized control technique of electrical vehicles propulsion system with dual PMSM connection," in Proc. IEEE Energy Convers. Congr. Expo., Sep. 2011, pp. 1708-1712.

[8] Y. S. Lai, C. A. Yeh, and K. M. Ho, "A family of predicive digitalcontrolled PFC under boundary current mode control," IEEE Trans. Ind. Informatics, vol. 8, no. 3, pp. 448-458, Aug. 2012.

[9] Y. Jang, G. Feng, and M. M. Jovanovic, "Interleaved boost bonverter with Intrinsic voltage-doubler characteristic for universal-line PFC front end," IEEE Trans. Power Electron., vol. 22, no. 4, pp. 1394-1401, Jul. 2007.

[10] M. A. P. Andrade, L. Schuch, and J. R. Pinheiro, "Generalized switching logic scheme for CCM-PFC interleaved boost converters," in Proc. IEEE Power Electron. Spec. Conf., 2004, pp. 2353-2359.

[11] Y. Gu and D. Zhang, "Interleaved boost converter with ripple cancellation network," IEEE Trans. Power Electron., vol. 28, no. 8, pp. 3860-3869, Aug. 2013.

[12] Y. T. Chen, S. Shiu, and R. Liang, "Analysis and design of a zero-voltageswitching and zero-current-switching interleaved boost converter," IEEE Trans. Power Electron., vol. 27, no. 1, pp. 161-173, Jan. 2012.

[13] T. Grote, H. Figge, N. Fr"ohleke, W. Beulen, F. Schafmeister, P. Ide, and J. B"ocker, "Semi-digital interleaved PFC control with optimized light load efficiency," in Proc. IEEE Appl. Power Electron. Conf. , 2009, pp. 1722- 1727.

[14]R. W. Erickson and D. Maksimovi'c, Fundamental of Power Electronics, 2nd ed. Norwell, MA, USA: Kluwer, 2001.

[15] Texas Instruments, Dallas, TX, USA, Datasheet TMS320 F2808, 2012.

[16] Panasonic, Kadoma, Japan, Motor Specifications MHMA302P1G, 2006. 